\title{
The role of Nuclear Erythroid Factor 2 (Nrf-2) in vascular reactivity of normotensive and spontaneously hypertensive rats
}

\author{
O papel do Fator Eritróide Nuclear 2 (Nrf-2) na Reatividade Vascular de Ratos Normotensos e \\ Espontaneamente Hipertensos \\ El papel del factor eritroide nuclear 2 (Nrf-2) en la reactividad vascular de ratas normotensas y \\ espontáneamente hipertensas
}

Received: 01/12/2022 | Reviewed: 01/16/2022 | Accept: 02/12/2022 | Published: 02/18/2022

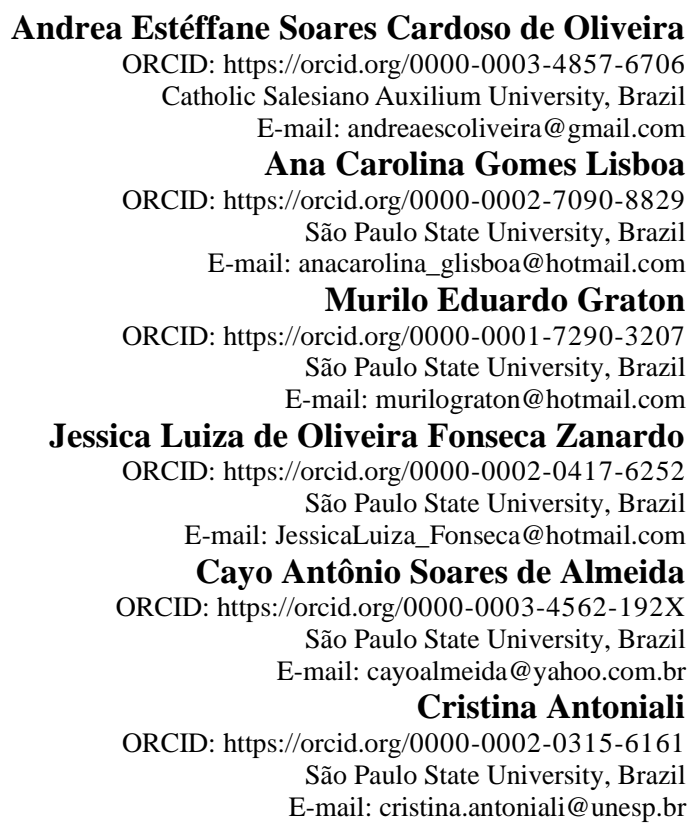

\begin{abstract}
The uncontrolled production of the reactive oxygen species (ROS) generates oxidative stress and the development of chronic diseases, such as hypertension. Antioxidant enzymes can reduce the cellular level of ROS. Nuclear erythroid factor 2 (Nrf-2) favors the expression and activity of antioxidant enzymes. In hypertensive rats, Nrf-2 expresssion appears to be reduced in blood vessels and, consequently, it favors the oxidative stress and vascular dysfunction. Apocynin (APO) has been considered a new antioxidant drug. APO reduces blood pressure, decreases ROS production, and improves endothelial function in spontaneously hypertensive rats (SHR). We hypothesized that the role of Nrf-2 in vascular reactivity is altered in SHR and APO-treatment prevents this alteration. To test this hypothesis, we evaluated aorta reactivity to phenylephrine (PE) and acetylcholine (ACh), in the absence and presence of Brusatol, Nrf-2 inhibitor. We used aortas from normotensive Wistar rats and SHR, untreated or treated with APO. Brusatol increased the reactivity of the aortas from SHR to PE, but did not change the reactivity of Wistar rat aortas. In APO-treated SHR aortas, the effect of Brusatol was not observed. The vasodilator responses to ACh were not modified by Brusatol in aortas from normotensive or hypertensive rats, untreated or treated with APO. These results suggest that Nrf-2 is activated in the contractile response to PE. In SHR aortas, exacerbated generation of ROS induces the activation of Nrf-2. This suggestion is reinforced by the lack of Brusatol effect in APO-treated SHR aortas. As APO is an antioxidant drug, the reduction of ROS in vascular cells would not lead to Nrf-2 activation.
\end{abstract}

Keywords: Hypertension; SHR; Aorta; Oxidative stress; Nrf-2.

\section{Resumo}

A produção não controlada de espécies reativas de oxigênio (ERO) induz ao estresse oxidativo e ao desenvolvimento de doenças crônicas como a hipertensão. Enzimas antioxidantes podem reduzir o nível celular de ROS. O fator eritroide nuclear 2 (Nrf-2) favorece a expressão e atividade de enzimas antioxidantes. Em ratos hipertensos, a 
Research, Society and Development, v. 11, n. 3, e18711325646, 2022

(CC BY 4.0) | ISSN 2525-3409 | DOI: http://dx.doi.org/10.33448/rsd-v11i3.25646

expressão de Nrf-2 parece estar reduzida nos vasos sanguíneos e, consequentemente, favorece o estresse oxidativo e a disfunção vascular. A apocinina (APO) tem sido considerada uma nova droga antioxidante. APO reduz a pressão arterial, diminui a produção de ROS e melhora a função endotelial em ratos espontaneamente hipertensos (SHR). Nós hipotetizamos que o papel do Nrf-2 na reatividade vascular é alterado no tratamento com SHR e APO previne essa alteração. Para testar essa hipótese, avaliamos a reatividade da aorta à fenilefrina (PE) e acetilcolina (ACh), na ausência e na presença de Brusatol, inibidor de Nrf-2. Foram utilizadas aortas de ratos Wistar e SHR normotensos, não tratados ou tratados com APO. Brusatol aumentou a reatividade das aortas de SHR para PE, mas não alterou a reatividade das aortas de ratos Wistar. Em aortas SHR tratadas com APO, o efeito de Brusatol não foi observado. As respostas vasodilatadoras à ACh não foram modificadas pelo Brusatol em aortas de ratos normotensos ou hipertensos, não tratados ou tratados com APO. Esses resultados sugerem que o Nrf-2 é ativado na resposta contrátil à PE. Em aortas SHR, a geração exacerbada de ROS induz a ativação de Nrf-2. Essa sugestão é reforçada pela falta de efeito do Brusatol em aortas SHR tratadas com APO. Como a APO é um fármaco antioxidante, a redução de ROS nas células vasculares não levaria à ativação do Nrf-2.

Palavras-chave: Hipertensão; SHR; Aorta; Estresse oxidativo; Nrf-2.

\section{Resumen}

La producción descontrolada de especies reactivas de oxígeno (ERO) induce estrés oxidativo y el desarrollo de enfermedades crónicas como la hipertensión. Las enzimas antioxidantes pueden reducir el nivel celular de ROS. El factor 2 eritroide nuclear (Nrf-2) favorece la expresión y actividad de enzimas antioxidantes. En ratas hipertensas, la expresión de Nrf-2 parece estar reducida en los vasos sanguíneos y, en consecuencia, favorece el estrés oxidativo y la disfunción vascular. La apocinina (APO) se ha considerado un nuevo fármaco antioxidante. APO reduce la presión arterial, disminuye la producción de ROS y mejora la función endotelial en ratas espontáneamente hipertensas (SHR). Presumimos que el papel de Nrf-2 en la reactividad vascular se altera en el tratamiento de SHR y APO previene esta alteración. Para probar esta hipótesis, evaluamos la reactividad de la aorta a la fenilefrina (PE) y la acetilcolina (ACh), en ausencia y presencia de Brusatol, inhibidor de Nrf-2. Se utilizaron aortas de ratas normotensas Wistar y SHR, no tratadas o tratadas con APO. Brusatol aumentó la reactividad aórtica de SHR a PE, pero no cambió la reactividad aórtica de las ratas Wistar. En aortas SHR tratadas con APO, no se observó el efecto de Brusatol. Brusatol no modificó las respuestas vasodilatadoras a la ACh en aortas de ratas normotensas o hipertensas, no tratadas o tratadas con APO. Estos resultados sugieren que Nrf-2 se activa en la respuesta contráctil a PE. En aortas SHR, la generación exacerbada de ROS induce la activación de Nrf-2. Esta sugerencia se ve reforzada por la falta de efecto de Brusatol en aortas SHR tratadas con APO. Como APO es un fármaco antioxidante, la reducción de ROS en las células vasculares no conduciría a la activación de Nrf-2.

Palabras clave: Hipertensión; SHR; Aorta; Estrés oxidativo; Nrf-2.

\section{Introduction}

Cardiovascular diseases are the leading cause of death, hospitalizations and outpatient care on a global scale. According to 2017 data, carried out by Datasus, the occurrence of deaths in Brazil reached a percentage of $27.3 \%$ for cardiovascular diseases, and hypertension was associated with $45 \%$ of the cardiac deaths: coronary artery disease and heart failure (Barroso et al., 2021). Hypertension is a generally asymptomatic condition, and it usually evolves structural and functional changes in target organs, such as the heart, vessels, brain and kidneys. This alteration contributes to the high impact in morbidity and mortality and hospital and socioeconomic costs. The prevalence of arterial hypertension has increased in underdeveloped and developing countries, which can be explained, in part, by the regional heterogeneity of risk factors such as high sodium and low potassium consumption, obesity, alcohol consumption and sedentary lifestyle. In contrast to the increasing prevalence, prevention, control and treatment of hypertension are less than expected (Mills et al., 2020). In recent decades, with the spread of the use of antihypertensive drugs, the global mean arterial pressure has remained constant or has been reduced in a negligible way. Because of this, there is a global need for investments in more effective antihypertensive therapies to reduce morbidity and mortality of the population (Barroso et al., 2021; Mills et al., 2020).

To analyze the mechanism of arterial hypertension it is necessary to understand the pathophysiology of this chronic disease. Hypertension is highly related to oxidative stress, which is defined as the imbalance between reactive oxygen species (ROS) production and antioxidant defenses (Betteridge, 2000; Montezano et al., 2015). ROS are constantly generated from cellular metabolism and when produced in a controlled manner, they act physiologically in the body, regulating different 
Research, Society and Development, v. 11, n. 3, e18711325646, 2022

(CC BY 4.0) | ISSN 2525-3409 | DOI: http://dx.doi.org/10.33448/rsd-v11i3.25646

cellular processes. However, the excessive generation of ROS results in oxidative stress that causes cell damage and contributes to the development of chronic diseases such as high blood pressure (Ma, 2013; McIntyre, Bohr \& Dominiczak, 1999). Oxidative stress favors the translocation and transcription of nuclear erythroid factor 2 (Nrf-2) to the nucleus. Nrf-2 plays an important role in the cellular redox system, as it is expressed in different tissues and regulates the expression of genes that encode antioxidant enzymes, such as glutathione peroxidase (GPx), superoxide dismutase (SOD), catalase (CAT) and heme-oxygenase 1 (HO-1), by linking to the antioxidant response elements in the promoter segments of the corresponding genes (Pecorelli et al., 2013). Nrf-2 serum level is reduced in spontaneously hypertensive rats (SHR) and contributes to low antioxidant capacity, thus intensifying oxidative stress and vascular dysfunction (Erejuwa et al., 2012). Activation of Nrf-2 in SHR was effective in increasing endothelium-dependent vasodilation, reversing the redox imbalance (Lopes et al., 2015) and reducing oxidative stress, in addition to attenuating the progression of hypertension (Javkhedkar; Banday, 2015).

APO has shown a promising application in reducing arterial hypertension in hypertensive animals (Virdis et al., 2016). APO is constituent of extracts from the root of the Picrorhiza kurroa plant, and it has been widely used in experimental studies as an antioxidant drug. One of its functions includes inhibiting the generation of ROS, contributing to the reduction of oxidative stress and vascular damage (Rosa et al., 2016). Our group reported chronic treatment with APO (30 mg/kg, po) increased the hypotensive effect of acetylcholine and its vasodilator responses in SHR. Moreover, APO treatment increased the bioavailability of nitric oxide (NO) and reduced ROS and oxidative stress in treated SHR, preventing the endothelial dysfunction in SHR blood vessels (Perassa et al., 2016). Besides that, APO treatment was effective in reducing the expression of NOX2 and p47phox and the activity of NAD(P)H oxidase enzymes in SHR blood vessels (Graton et al., 2019).

Taken together, these data led us to raise the hypothesis that the role of Nrf-2 in the vascular reactivity is altered in SHR blood vessel and APO treatment would be able prevent this alteration. To better understand the role of Nrf- 2 in vascular reactivity, we analyzed the effect of Brusatol, used as Nrf-2 inhibitor, which promotes rapid and transient depletion of the Nrf2 protein (Olayanju et al., 2015).

\section{Methodology}

The experiments were performed following the standardized methodology published in previous studies (Perassa et al., 2016; Graton et al., 2019).

\subsection{Animals}

The experimental protocols were previously approved by the Local Ethics Committee (CEUA 0855-2017) of the São Paulo State University "Júlio Mesquita Filho", following the regulations of the current legislation $n^{\circ}$ 8112/2008, of the National Council for the Control of Animal Experiments (CONCEA). Mating was performed between male and female SHR with systolic blood pressure (SBP) greater than or equal to $150 \mathrm{mmHg}$. SBP was verified by tail plethysmography using a plethysmograph for measurements in rats (PowerLab, ADInstruments, Australia). The male SHR offspring (50g, 4-week-old) were used in the experiments. Wistar rats, in the same age, were used as normotensive controls. The animals were kept under temperature-controlled conditions $\left(22-24^{\circ} \mathrm{C}\right)$ with a light/dark cycle $(12 \mathrm{~h} / 12 \mathrm{~h})$, received standard commercial rodent chow and water ad libitum.

\subsection{Drugs and treatment}

For this experimental design Apocynin (APO, SIGMA) diluted in drinking water was used to treat the animals. Brusatol (Nrf-2 inhibitor, SIGMA), Acetylcholine (ACh, vasodilator, SIGMA) and Phenylephrine (PE, vasoconstrictor, 
Research, Society and Development, v. 11, n. 3, e18711325646, 2022

(CC BY 4.0) | ISSN 2525-3409 | DOI: http://dx.doi.org/10.33448/rsd-v11i3.25646

SIGMA) were used in the vascular reactivity experiments. Animals were carefully grouped according to previously established protocols. Thus, four groups were obtained: Control Wistar rats $(n=9)$, Treated Wistar rats $(n=6)$, SHR $(n=11)$ and Treated SHR $(n=9)$. Treated groups received APO $(30 \mathrm{mg} / \mathrm{kg}$, po) diluted in drinking water and untreated groups drank water without addition of APO for 6 weeks, starting from the fourth week of life. The body weight from animals was checked twice a week to adjust the established dose per kilogram. The dose of APO used to treat the animals was determined based on previous studies that observed the hypotensive effect of APO without toxicity (Baümer et al., 2007; Hayashi et al., 2005; Oelze et al., 2011; Pechanová et al., 2009; Perassa et al., 2016; Graton et al., 2019). After 6 weeks of treatment, SBP was measured by plethysmography and then animals were sacrificed with an overdose of anesthetic.

\subsection{Vascular reactivity}

The thoracic aorta of each animal was dissected, extracted, cleaned, and sectioned into rings of $2 \mathrm{~mm}$ in a Petri dish containing Krebs-Henseleit solution (composition in mmol/L: $\mathrm{NaCl} 130.0 ; \mathrm{KCl} 4.7 ; \mathrm{KH}_{2} \mathrm{PO}_{4} 1.2 ; \mathrm{MgSO}_{4} 1.2 ; \mathrm{NaHCO}_{3} 14.9$;


Australia). The aortic rings were positioned between two stainless steel hooks, connected to an isometric force transducer, and maintained in Krebs -Henseleit solution, $37{ }^{\circ} \mathrm{C}$, pH 7.4 with gaseous supply of $95 \%$ O2 and $5 \% \mathrm{CO} 2$ for a period of stabilization $(30 \mathrm{~min}$ ) at a basal tension of $30 \mathrm{mN}$. After $30 \mathrm{~min}$, the rings were stimulated with potassium chloride solution $120 \mathrm{mmol} / \mathrm{L}$ to test functional integrity of vascular cells. Rings with contractile responses $\geq 10 \mathrm{mN}$ to $\mathrm{KCl}$ were used in the experiments. After the contractile response plateau has been observed, the preparations were washed with a solution of KrebsHenseleit until to reach basal tension. Endothelial cells integrity was assessed by the relaxation responses induced by ACh (1 $\mu \mathrm{mol} / \mathrm{L})$ after PE (100 nmol/L) response. For Wistar rats, intact aortic rings with functional endothelium showed ACh relaxation response $\geq 90 \%$ and for SHR, aortic rings showed endothelium dysfunction and relaxation responses to ACh $\leq 70 \%$. Aortic rings without ACh responses were not used in these experiments. Concentration-effect curves for PE $(0.1 \mathrm{nmol} / \mathrm{L}-0.1$ $\mathrm{mmol} / \mathrm{L})$ were evaluated in aortic rings in the absence and presence of Brusatol $(0,1 \mu \mathrm{mol} / \mathrm{L})$ a specific inhibitor for Nrf-2.

\subsection{Statistical analysis}

Data were presented as mean \pm SEM and " $n$ " is the number of animals or aortic rings used in the experiments. All results were compared between groups using Student's t test or analysis of variance (One-away ANOVA) with Tukey's posttest. The statistical program GraphPad Prism 7.0 (GraphPad Software Corporation, La Jolla, USA) was used to make the graphs and to analyze the results and compare the results between the groups. Differences were considered significant when $\mathrm{p}$ $<0.05$.

\section{Results and Discussion}

\subsection{Evaluation of the effect Brusatol on the reactivity of aortas from Wistar and SHR rats to PE.}

Initially, to assess the role of Nrf-2 in the vascular reactivity to PE, we compared the PE concentration-effect curves obtained in the absence and in the presence of Brusatol, an inhibitor of Nrf-2, in intact aortas from Wistar rats (Figure 1A) or SHR (Figure 2A). We found that in the presence of Brusatol $(0,1 \mu \mathrm{mol} / \mathrm{L})$, there was a tendency towards the greater reactivity to PE, but not significant (Figure 1A). However, in SHR aortas (Figure 2A), we observed that Emax of the concentration-effect curves to PE were increased in the presence of Brusatol, demonstrating that Brusatol significantly increased the reactivity of aortas from SHR. These results show that aortas from hypertensive rats are more sensitive to the effect of Brusatol than aortas from normotensive rats and suggest the relevant role of Nrf-2 in the vascular contraction stimulated by PE in SHR aortas. 
Figure 1: Phenylephrine (PE) concentration-responses curves in aortic rings of untreated Wistars rats $(\mathrm{WC}, \mathrm{n}=5)$ and Wistars rats treated with APO (WT, $n=6)$, in the absence and presence of Brusatol $(+B)$. The points represent the mean \pm SEM of the results obtained. The results were compared between the curves and the differences were not significant.

\section{A}

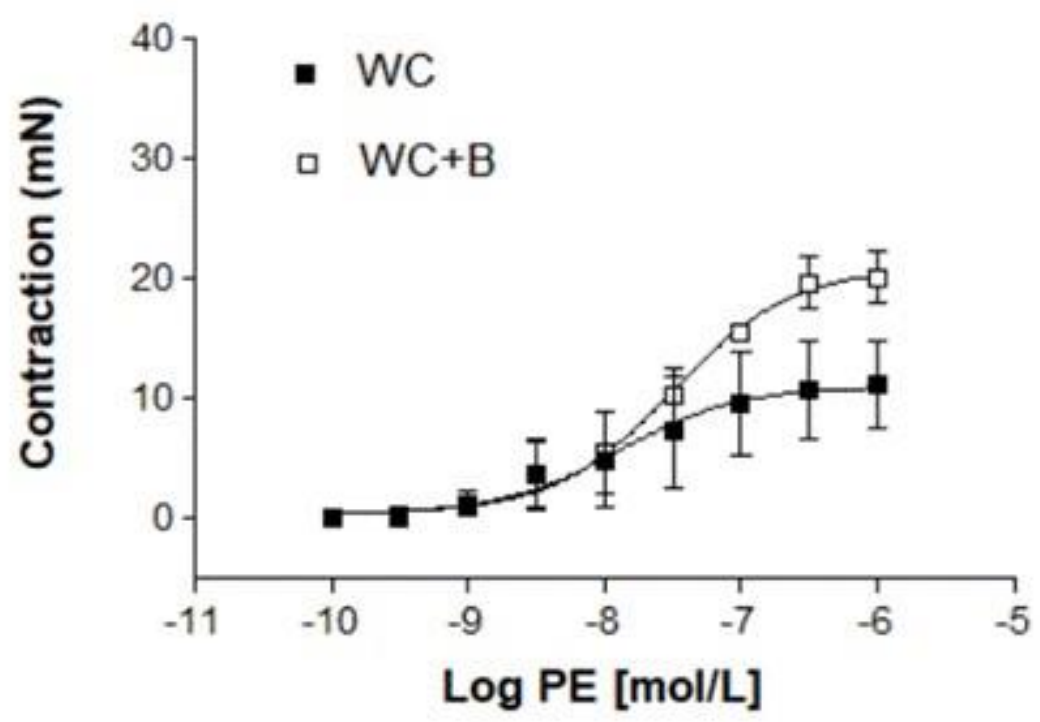

B

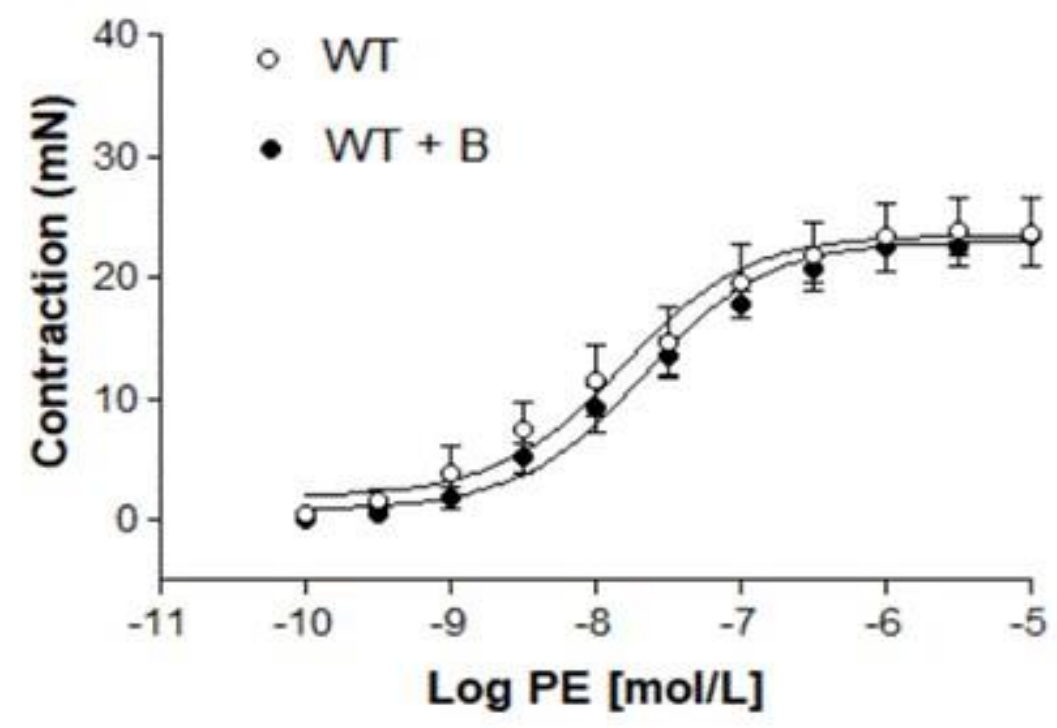

Source: Authors. 
Figure 2: Phenylephrine (PE) concentration-responses curves in aortic rings of untreated SHR (SHR C, n=7) and in aortic ring of APO-treated SHR (SHR T, $n=4$ ) in the absence and presence of Brusatol (+B). The points represent the mean \pm SEM of the results obtained. The results were compared between the curves, ${ }^{*} \mathrm{p}<0.05$

A

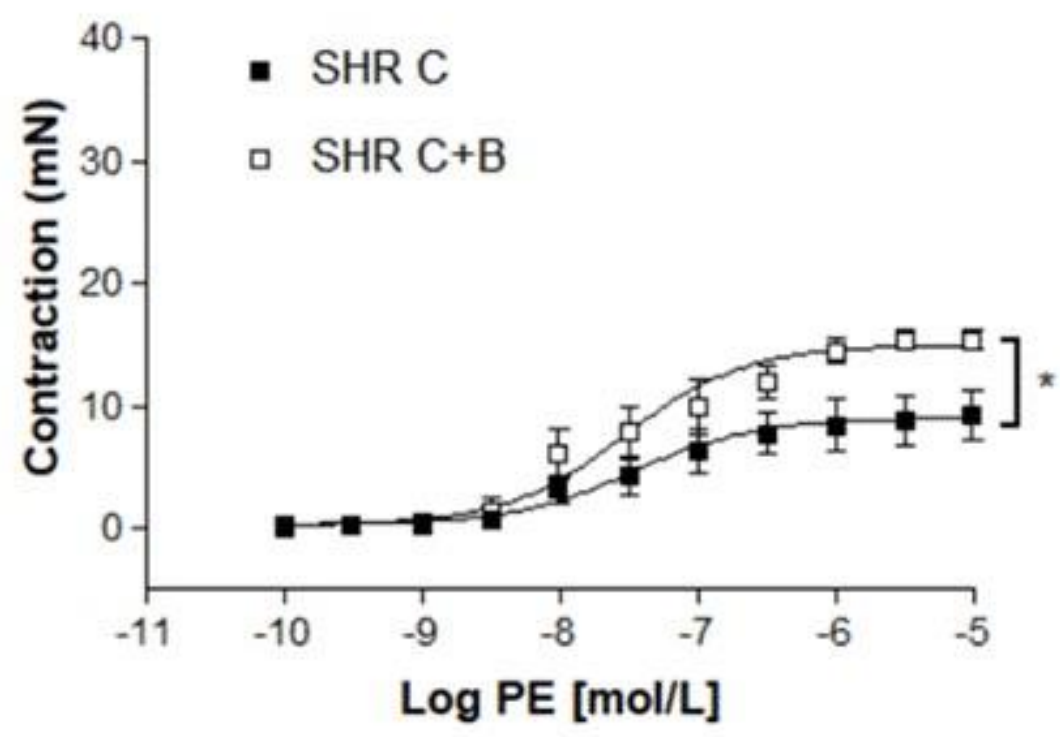

B

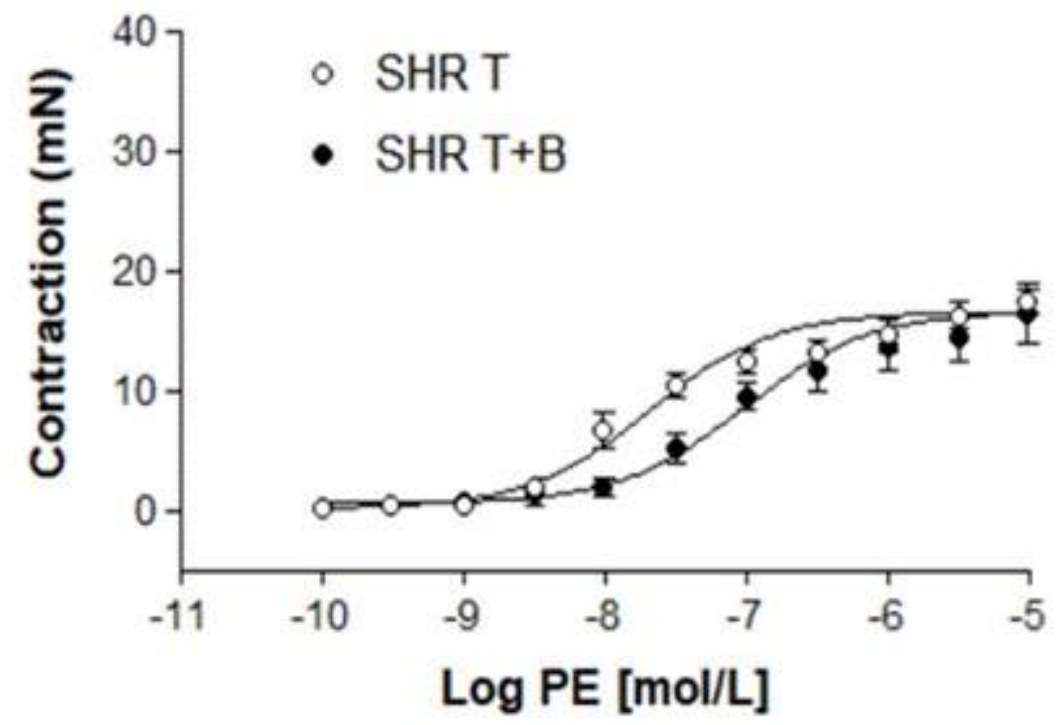

Source: Authors. 
Research, Society and Development, v. 11, n. 3, e18711325646, 2022

(CC BY 4.0) | ISSN 2525-3409 | DOI: http://dx.doi.org/10.33448/rsd-v11i3.25646

Previously results from our group demonstrated that Brusatol $(0.1 \mu \mathrm{mol} / \mathrm{L})$ was able to increase the reactivity to PE in intact aortic rings of female Wistar rats, however this effect of Brusatol was not observed in endothelium-denuded aortas from female Wistar rats (Zanardo, 2020). The lack of Brusatol effect in endothelium denuded aortic rings suggest that Nrf-2 is involved in the modulating effect of endothelium on vasoconstriction induced by PE. The vasoconstrictor responses to PE are modulated by endothelium-derived NO in aortic rings. As demonstrated in some of our studies, endothelium removal or preincubation with L-NAME, an inhibitor of NOS, increased PE responses in blood vessels of normotensive or hypertensive rats (Zancheta et al., 2015; Perassa et al., 2016; Graton et al., 2019).

In the presence of Brusatol, a greatest amount of ROS was measured in HUVEC (human umbilical vascular endothelial cells) (Zanardo, 2020) than in the absence of this inhibitor. Moreover, the basal amount of ROS is increased in SHR endothelial cells than in Wistar rat endothelial cells (Perassa et al., 2016). Considering that Brusatol is increasing ROS in endothelial cells, a highest amount of $\mathrm{O}_{2}{ }^{--}$would be expected in endothelial cells of SHR in the presence of Brusatol. The highest amount of $\mathrm{O}_{2}{ }^{--}$would reduce NO bioavailability and its anti-contractile effect. These results suggest that Brusatol is increasing ROS in aortas of hypertensive rats and consequently, Brusatol could reduce NO bioavailability and the modulating effect of the endothelium on the vasoconstrictor responses stimulated by the $\alpha 1$-adrenergic agonist.

To test this hypothesis, we evaluated the effect of Brusatol on aortas from rats treated with APO. Endothelial cells of aortas isolated from APO-treated SHR showed a significative increase in NO and a decreased in ROS when compared to the cells from SHR not treated with APO (Perassa et al., 2016). Moreover, APO reduced the lucigenin chemiluminescence, indicating that APO treatment reduces NOX activity in aortas of hypertensive rats (Graton et al., 2019). We observed that Brusatol did not change the PE reactivity in the aortas from APO-treated Wistar rats (Figure 1B). Likewise, Brusatol did not alter PE reactivity in APO-treated SHR aortas (Figure 2B). Although the curves were slightly shifted to the right in the presence of Brusatol, the difference in the $\mathrm{pD} 2$ values between the curves were not statistically significant in APO-treated SHR aortas.

Together, our results demonstrated that Brusatol significantly increases the reactivity of aortas from untreated SHR (Figure 2A) to PE, but its effect is not observed in APO-treated SHR aortas (Figure 2B). These results suggest that Nrf2 participates in the vascular response to PE in blood vessels of hypertensive rats. Probably Nrf-2 is involved in the modulating effect of the endothelium on PE reactivity, which depends on NO bioavailability.

\subsection{Evaluation of the effect of Brusatol on the reactivity of aortas from Wistar and SHR rats to ACh}

We also evaluated the effect of Brusatol on the reactivity of aortas to Acetylcholine (ACh). ACh promotes relaxation of the aortas. This effect is dependent on nitric oxide (NO), the relaxing factor derived from endothelium and synthesized by endothelial nitric oxide synthase (eNOS). We evaluated whether the relaxation pattern of aortic rings to ACh is altered by Brusatol. For this, the aortic rings were pre-contracted with PE, and relaxation was obtained from the addition of increasing and cumulative concentrations of ACh. ACh concentration-responses curves were compared between groups (Figure 3 and 4).

We observed that Brusatol did not alter the reactivity to ACh in aortas from untreated (Figure 3A) or APO-treated (Figure 3B) Wistar rats to ACh, suggesting the vasodilator response of ACh in aortas from normotensive rats does not depend on Nrf-2. 
Figure 3: Concentration-effect curves for $\mathrm{ACh}$ in aortic rings from untreated $(\mathrm{C}, \mathrm{n}=5)$ and APO-treated $(\mathrm{T}, \mathrm{n}=5)$ Wistar rats, in the absence and presence of Brusatol $(+B)$. The points represent the mean \pm SEM of the results obtained.

A

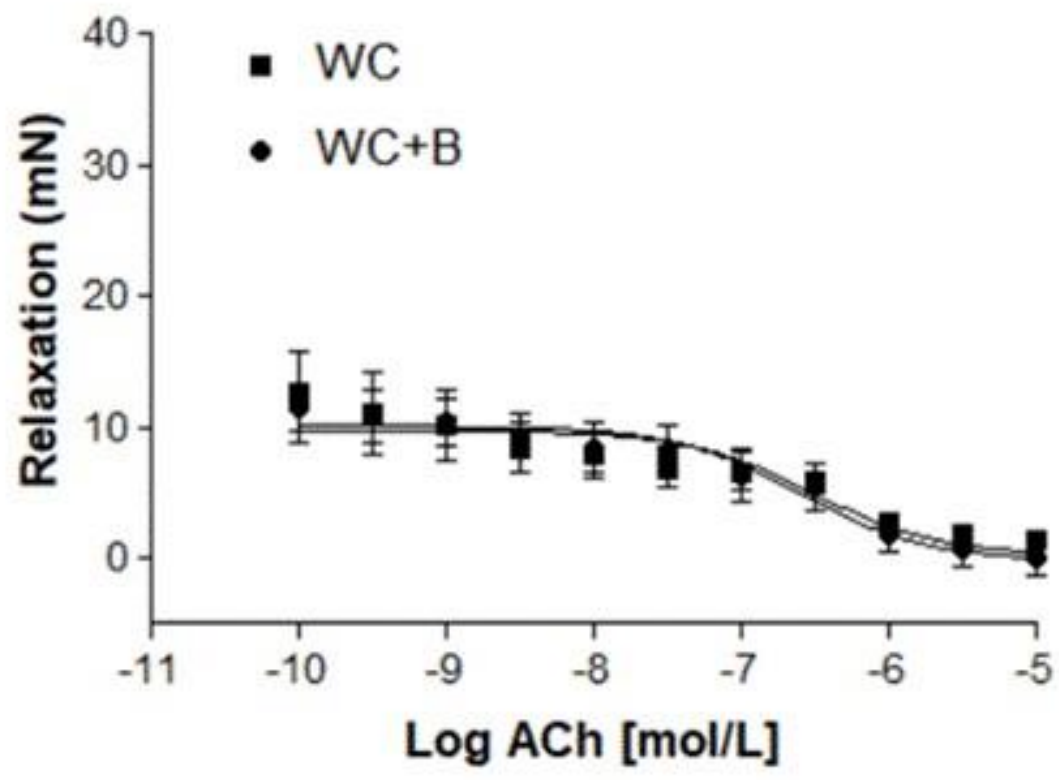

B

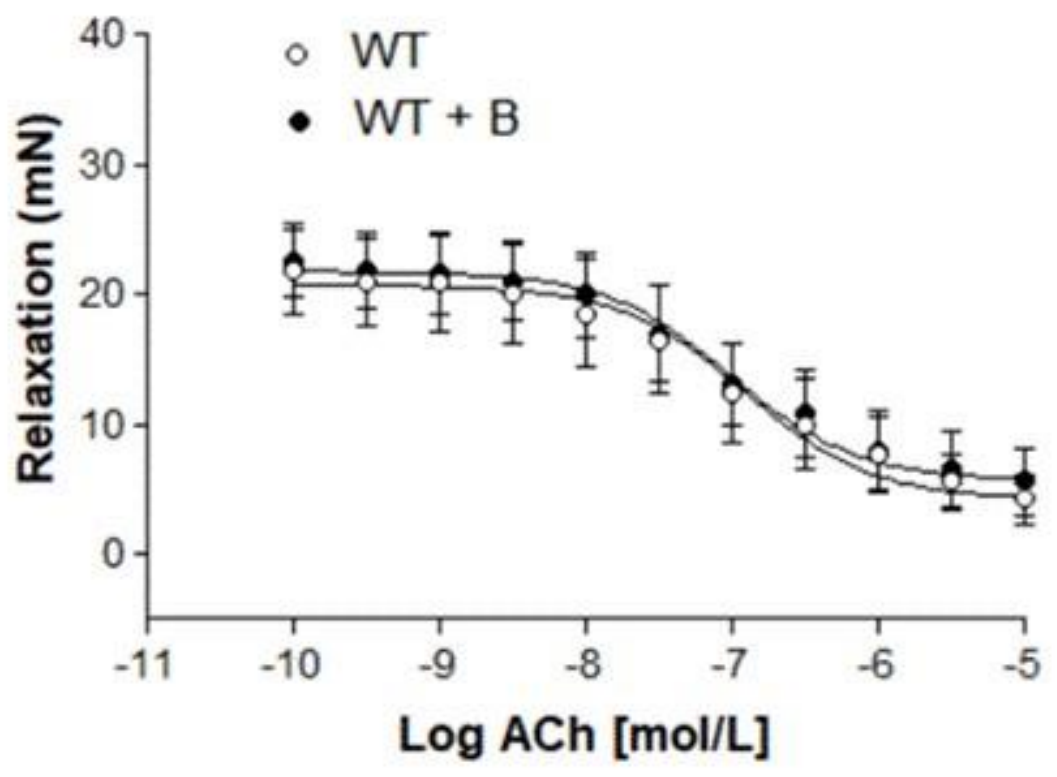

Source: Authors. 
Research, Society and Development, v. 11, n. 3, e18711325646, 2022

(CC BY 4.0) | ISSN 2525-3409 | DOI: http://dx.doi.org/10.33448/rsd-v11i3.25646

To verify the effect of Brusatol in relaxation induced by ACh in SHR aortic rings, we also evaluated the concentration-effect curves to ACh in absence or presence of Brusatol (Figure 4). ACh vasodilator responses are impaired in aortas from SHR. This functional alteration is a consequence of the endothelial dysfunction associated with hypertension. Endothelial dysfunction is characterized by lower eNOS activity and lower amounts of NO in endothelial cells. The increase in NOX activity and the highest amount of ROS in endothelial cells has also been associated with endothelial dysfunction in SHR.

APO treatment improves endotelial function in SHR blood vessels. Mesenteric arteries and aorta from APO-treated SHR showed increased sensitivity to ACh (Selemidis et al., 2008). Higher NO amount, lower NOX2 and p47phox expression, and reduced NOX activity were also observed in blood vessels of APO-treated SHR When compared to untreated SHR (Perassa et al., 2016, Graton et al., 2019).

Brusatol did not alter the impaired reactivity of aortas from untreated SHR to ACh (Figure 4A) and did not change the reactivity of aortas from APO-treated SHR to ACh (Figure 4B). 
Figure 4: Concentration-effect curves for $\mathrm{ACh}$ in untreated $(\mathrm{A}, \mathrm{n}=4)$ and APO-treated $(\mathrm{B}, \mathrm{n}=3) \mathrm{SHR}$ aortic rings in the absence and presence of Brusatol $(+B)$. The points represent the mean \pm SEM of the results obtained. The results were compared between the curves.

A

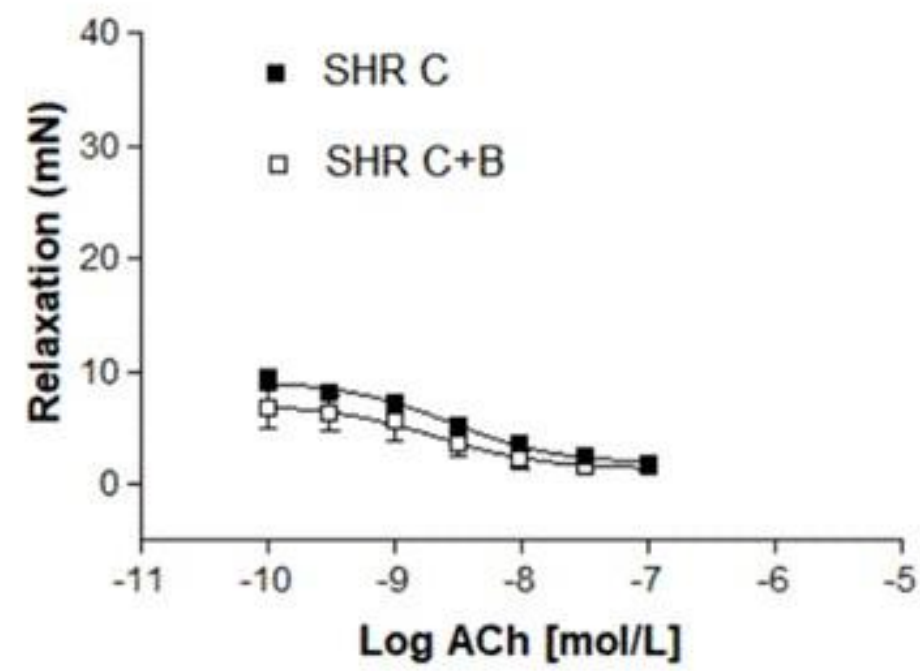

B

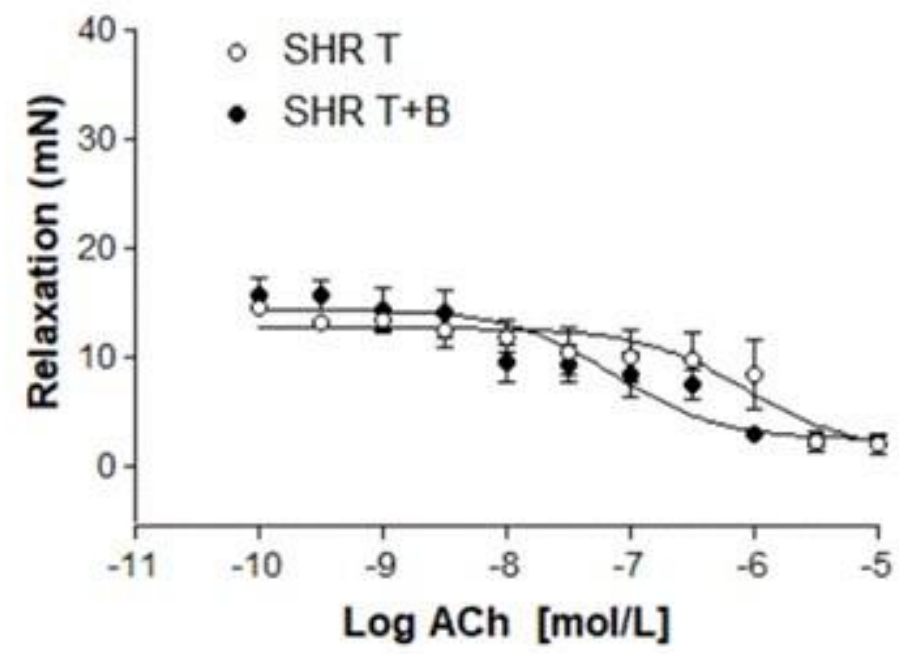

Source: Authors. 
Research, Society and Development, v. 11, n. 3, e18711325646, 2022

(CC BY 4.0) | ISSN 2525-3409 | DOI: http://dx.doi.org/10.33448/rsd-v11i3.25646

\section{Conclusion}

The results presented in this study showed Brusatol, an inhibitor of Nrf-2, increased the reactivity aortas to PE, but not to ACh. These results suggest that Nrf-2 is activated and participates in the contractile response to PE.

The effect of Brusatol is significantly increased in aortas from hypertensive rats than in aortas from normotensive rats. In aortas from hypertensive rats, increased generation of ROS induces the activation of Nrf-2, a transcription factor for an antioxidant response element. This suggestion is reinforced by the lack of effect of Brusatol in APO-treated SHR aortas. As APO is an antioxidant drug, it would reduce ROS in vascular cells and would not lead to Nrf-2 activation. Based on these findings, in the next steps of this study we will evaluate the effect of Brusatol and Apocynin on the expression of Nrf2 signaling pathway proteins in SHR aortas. Altogether, our data are promising and open possibilities for interpreting the effects of APO and Brusatol in hypertensive individuals.

\section{Acknowledgments}

We are grateful for the financial support received from Fundação de Amparo à Pesquisa do Estado de São Paulo (FAPESP, grant number 2016/22180-9), Coordenação de Aperfeiçoamento de Pessoal de Nível Superior - Brasil (CAPES) Finance Code 001, and Conselho Nacional de Desenvolvimento Científico e Tecnológico (CNPq). AESCO is recipient from Institutional Scientific Initiation Scholarship Program (PIBIC-CNPq, process number 121573/2021-4).

\section{References}

Barroso, W. K. S. et al. (2020). Brazilian Guidelines of Hypertension. Arq Bras Cardiol. 116 (3): 516-658. doi: 10.36660/abc.20201238.

Bäumer, A. T., Krüger, C. A., Falkenberg, J., Freyhaus, H. T., Rösen, R., Fink, K., \& Rosenkranz, S. (2007). The NAD(P)H oxidase inhibitor apocynin improves endothelial $\mathrm{NO} /$ superoxide balance and lowers effectively blood pressure in spontaneously hypertensive rats: comparison to calcium channel blockade. Clin Exp Hypertens. 29 (5): 287-99. doi: 10.1080/10641960701500398.

Erejuwa, O. O., Sulaiman, S. A. A., Wahab, M. S., Sirajudeen, K. N., Salleh, S., \& Gurtu, S. (2012). Honey supplementation in spontaneously hypertensive rats elicits antihypertensive effect via amelioration of renal oxidative stress. Oxid Med Cell Longev. 2012:374037. doi: 10.1155/2012/374037.

Graton, M. E., Potje, S. R., Troiano, J. A., Vale, G. T., Perassa, L. A., Nakamune, A. C. M. S., Tirapelli, C. R., Bendhack, L. M., \& Antoniali, C. (2019). Apocynin alters redox signaling in conductance and resistance vessels of spontaneously hypertensive rats. Free Radic Biol Med. 134: 53-63. doi: 10.1016/j.freeradbiomed.2018.12.026.

Hayashi, T., Juliet, P. A., Kano-Hayashi, H., Tsunekawa, T., Dingqunfang, D., Sumi, D., Matsui-Hirai, H., Fukatsu, A., \& Iguchi, A. (2005). NADPH oxidase inhibitor, apocynin, restores the impaired endothelial-dependent and -independent responses and scavenges superoxide anion in rats with type 2 diabetes complicated by NO dysfunction. Diabetes Obes Metab. 7 (4): 334-43. doi: 10.1111/j.1463-1326.2004.00393.x.

Javkhedkar, A. A., Quiroz, Y., Rodriguez-Iturbe, B., Vaziri, N. D., Lokhandwala, M. F., \& Banday, A. A. (2015). Resveratrol restored Nrf2 function, reduced renal inflammation, and mitigated hypertension in spontaneously hypertensive rats. Am J Physiol Regul Integr Comp Physiol. 15;308(10):R840-6. doi: 10.1152/ajpregu.00308.2014.

Lopes, R. A., Neves, K. B., Tostes, R. C., Montezano, A. C., \& Touyz, R. M. (2015). Downregulation of Nuclear Factor Erythroid 2-Related Factor and Associated Antioxidant Genes Contributes to Redox-Sensitive Vascular Dysfunction in Hypertension. Hypertension. 66 (6): 1240-50. doi: 10.1161/HYPERTENSIONAHA.115.06163.

Ma, Q. (2013). Role of nrf-2 in oxidative stress and toxicity. Annu Rev Pharmacol Toxicol. 53: 401-26. doi: 10.1146/annurev-pharmtox-011112-140320.

McIntyre, M., Bohr, D. F., \& Dominiczak, A. F. (1999). Endothelial function in hypertension: the role of superoxide anion. Hypertension. 34 (4 Pt 1): $539-45$. doi: 10.1161/01.hyp.34.4.539.

Mills, K. T., Stefanescu, A., He, J. (2020). The global epidemiology of hypertension. Nat Rev Nephrol.16 (4): 223-237. doi: 10.1038/s41581-019-0244-2.

Montezano, A. C., Dulak-Lis, M., Tsiropoulou, S., Harvey, A., Briones, A. M., \& Touyz, R. M. (2015). Oxidative stress and human hypertension: vascular mechanisms, biomarkers, and novel therapies. Can J Cardiol. 31 (5): 631-41. doi: 10.1016/j.cjca.2015.02.008.

Oelze, M., Knorr, M., Schuhmacher, S., \& Heeren, T., Otto, C., Schulz, E., Reifenberg, K., Wenzel, P., Münzel, T., \& Daiber, A. (2011). Vascular dysfunction in streptozotocin-induced experimental diabetes strictly depends on insulin deficiency. J Vasc Res. 48 (4): 275-84. doi: 10.1159/000320627.

Olayanju, A., Copple, I. M., Bryan, H. K., Edge, G. T., Sison, R. L., Wong, M. W., Lai, Z. Q., Lin, Z. X., Dunn, K., Sanderson, C. M., Alghanem, A. F., Cross, M. J., Ellis, E. C., Ingelman-Sundberg, M., Malik, H. Z., Kitteringham, N. R., Goldring, C. E. \& Park, B. K (2015). Brusatol provokes a rapid and 
Research, Society and Development, v. 11, n. 3, e18711325646, 2022

(CC BY 4.0) | ISSN 2525-3409 | DOI: http://dx.doi.org/10.33448/rsd-v11i3.25646

transient inhibition of Nrf2 signaling and sensitizes mammalian cells to chemical toxicity-implications for therapeutic targeting of Nrf2. Free Radic Biol Med. 78: 202-12. doi: 10.1016/j.freeradbiomed.2014.11.003.

Pechánová, O., Jendeková, L., \& Vranková, S. (2009). Effect of chronic apocynin treatment on nitric oxide and reactive oxygen species production in borderline and spontaneous hypertension. Pharmacol Rep. 61 (1): 116-22. doi: 10.1016/s1734-1140(09)70013-1.

Pecorelli, A., Bocci, V., Acquaviva, A., Belmonte, G., Gardi, C., Virgili, F., Ciccoli, L., Valacchi, G. (2013). NRF2 activation is involved in ozonated human serum upregulation of HO-1 in endothelial cells. Toxicol Appl Pharmacol. 15; 267 (1): 30-40. doi: 10.1016/j.taap.2012.12.001.

Perassa, L. A., Graton, M. E., Potje, S. R., Troiano, J. A., Lima, M. S., Vale, G. T., Pereira, A. A., Nakamune, A. C., Sumida, D. H., Tirapelli, C. R. Bendhack, L. M., \& Antoniali, C. (2016). Apocynin reduces blood pressure and restores the proper function of vascular endothelium in SHR. Vascul Pharmacol. 87: 38-48. doi: 10.1016/j.vph.2016.06.005.

Rosa, C. M., Gimenes, R., Campos, D. H., Guirado, G. N., Gimenes, C., Fernandes, A. A., Cicogna, A. C., Queiroz, R. M., Falcão-Pires, I., Miranda-Silva, D., Rodrigues, P., Laurindo, F. R., Fernandes, D. C., Correa, C. R., Okoshi, M. P., \& Okoshi, K. (2016) Apocynin influence on oxidative stress and cardiac remodeling of spontaneously hypertensive rats with diabetes mellitus. Cardiovasc Diabetol. 1; 15 (1): 126. doi: 10.1186/s12933-016-0442-1.

Selemidis, S., Sobey, C. G., Wingler, K., Schmidt, H. H., \& Drummond, G. R. (2008). NADPH oxidases in the vasculature: molecular features, roles in disease and pharmacological inhibition. Pharmacol Ther. 120 (3): 254-91. doi: 10.1016/j.pharmthera.2008.08.005.

Virdis, A., Gesi, M., \& Taddei, S. (2016). Impact of apocynin on vascular disease in hypertension. Vascul Pharmacol. 87:1-5. doi: 10.1016/j.vph.2016.08.006.

Zanardo, J. L. O. F. (2020). A via Nrf2 participa da maior modulação endotelial induzida pela prenhez sobre reatividade de aortas à fenilefrina. Dissertação (Mestrado). Universidade Estadual Paulista. 86 páginas. https://repositorio.unesp.br/handle/11449/193614

Zancheta, D., Troiano, J. A., Potje, S. R., Cavalari, P., Sumida, D. H., \& Antoniali, C. (2015). The PI3K-Akt-eNOS pathway is involved in aortic hyporeactivity to Phenylephrine associated with late pregnancy in spontaneously hypertensive rats. Life Sci. 1;122: 78-86. doi: 10.1016/j.lfs.2014.12.014. 